\title{
Simultaneous detection of papaya ringspot virus, papaya leaf distortion mosaic virus, and papaya mosaic virus by multiplex real-time reverse transcription PCR
}

\author{
P. HUO\#, W. T. SHEN", P YAN, D. C. TUO, X. Y. LI, P ZHOU*
}

Key Laboratory of Biology and Genetic Resources of Tropical Crops, Ministry of Agriculture, Institute of Tropical Bioscience and Biotechnology, Chinese Academy of Tropical Agricultural Sciences, Haikou 571101, P. R. China

Received May 6, 2015; accepted October 12, 2015

\begin{abstract}
Summary. - Both the single infection of papaya ringspot virus (PRSV), papaya leaf distortion mosaic virus (PLDMV) or papaya mosaic virus (PapMV) and double infection of PRSV and PLDMV or PapMV which cause indistinguishable symptoms, threaten the papaya industry in Hainan Island, China. In this study, a multiplex real-time reverse transcription PCR (RT-PCR) was developed to detect simultaneously the three viruses based on their distinctive melting temperatures (Tms): $81.0 \pm 0.8^{\circ} \mathrm{C}$ for PRSV, $84.7 \pm 0.6^{\circ} \mathrm{C}$ for PLDMV, and $88.7 \pm 0.4^{\circ} \mathrm{C}$ for PapMV. The multiplex real-time RT-PCR method was specific and sensitive in detecting the three viruses, with a detection limit of $1.0 \times 10^{1}, 1.0 \times 10^{2}$, and $1.0 \times 10^{2}$ copies for PRSV, PLDMV, and PapMV, respectively. Indeed, the reaction was 100 times more sensitive than the multiplex RT-PCR for PRSV, and 10 times more sensitive than multiplex RT-PCR for PLDMV. Field application of the multiplex real-time RT-PCR demonstrated that some non-symptomatic samples were positive for PLDMV by multiplex real-time RT-PCR but negative by multiplex RT-PCR, whereas some samples were positive for both PRSV and PLDMV by multiplex real-time RT-PCR assay but only positive for PLDMV by multiplex RT-PCR. Therefore, this multiplex real-time RT-PCR assay provides a more rapid, sensitive and reliable method for simultaneous detection of PRSV, PLDMV, PapMV and their mixed infections in papaya.
\end{abstract}

Keywords: papaya ringspot virus; papaya leaf distortion mosaic virus; papaya mosaic virus; multiplex realtime reverse transcription PCR

\section{Introduction}

Papaya (Carica papaya L.) is an economically important fruit crop for its high nutritive and medicinal value in tropical and subtropical areas (Schweiggert et al., 2014). However, papaya ringspot virus (PRSV; the family Potyviridae, the genus Potyvirus), papaya leaf distortion mosaic virus (PLDMV; the family Potyviridae, the genus Potyvirus), and papaya mosaic

*Corresponding authors. E-mail: dnaswt@hotmail.com; phone: +86 898 66890687. "These authors contributed equally to this work. Abbreviations: PapMV = papaya mosaic virus; PLDMV = papaya leaf distortion mosaic virus; PRSV = papaya ringspot virus; RT$\mathrm{PCR}=$ reverse transcription PCR; $\mathrm{Tm}=$ melting temperature virus (PapMV; the family Flexiviridae, the genus Potexvirus) had been detected and threatened commercial production of papaya in China (Bau et al., 2008; Lu et al., 2008; Shen et al., 2014a; Tuo et al., 2013). These three viruses produce visually indistinguishable symptoms in papaya such as mosaic, yellow-green discoloration and distortion on leaves, and water-soaking streaks on petioles (Gonsalves, 1998; Maoka et al., 1996; Sit and AbouHaidar, 1993). Among the three papaya viruses, PRSV was considered the most widespread and destructive disease damaging papaya production in the world including China (Ye and Li, 2010; Lu et al., 2008). PLDMV was detected recently in papaya plants including PRSV-resistant transgenic papaya in Taiwan and Hainan Island (Bau et al., 2008; Tuo et al., 2013, 2014), representing a new threat to papaya production in China. Moreover, 
although rarely found, PapMV was also detected in papaya fields (Cruz et al., 2009; Noa-Carrazana et al., 2006; Shen et al., 2014a). Furthermore, mixed infections of PRSV and PLDMV or PapMV reported in papaya in China and the Philippines, caused indistinguishable symptoms in plants singly infected with PRSV, PLDMV or PapMV (Cruz et al., 2009; Shen et al., 2014b; Tuo et al., 2014). Therefore, it is essential to develop a rapid and effective diagnostic method for simultaneous detection of these three viruses in papaya.

Many diagnostic techniques have been applied in the detection of PRSV, PLDMV, or PapMV, such as ELISA, Western blotting, conventional RT-PCR, real-time RT-PCR, and reverse transcription loop-mediated isothermal amplification (RT-LAMP) (Chiang et al., 2001; Cruz et al., 2009; Ling et al., 1991; Noa-Carrazana et al., 2006; Shen et al., 2010; Shen et al., 2014c; Tuo et al., 2014). Although valuable for detecting papaya virus, the techniques described above can only detect individual papaya viruses in each reaction. For large-scale surveillance of single and mixed infections, cost effective and time-saving methods for the detection of these three viruses are needed. Recently developed multiplex RT-PCR to detect simultaneously PRSV, PLDMV, and PapMV provides a fast and reliable diagnostic tool for the simultaneous amplification of more than one target sequence in a single reaction. (Tuo et al., 2014). However, many studies have shown that real-time RT-PCR has a higher sensitivity as compared with conventional RT-PCR, which has been widely used to simultaneously identify different plant and animal viruses based on different melting temperatures (Tm) of each virus-derived PCR product (Nicolas et al., 2002; Pérez et al., 2012; Ririe et al., 1997; Sharma and Dasgupta, 2012; Varga and James, 2006). In this study, we developed a multiplex real-time PCR based on SYBR Green I dye for the simultaneous detection of PRSV, PLDMV, and PapMV, which provides a new, simple, and reliable method for the detection of papaya virus.

\section{Materials and Methods}

Viruses source. The PRSV (GenBank Acc. Nos. KF791028, HQ424465 and EF183499), PLDMV (GenBank Acc. Nos. JX974555), and PapMV (GenBank Accession Nos. JX524226) strains isolated from Hainan, China were used as the positive controls in this study and propagated in papaya plants (Lu et al., 2008; Tuo et al., 2013; Shen et al., 2014a).

Primer design. About 22 genomic sequences of PRSV including PRSV-P and PRSV-W isolates selected from GenBank database (Acc. Nos. AB369277, AY010722, AY027810, AY162218, AY231130, DQ340769, DQ340770, DQ340771, DQ374152, DQ374153, EF017707, EF183499, EU126128, HQ424465, JX448369, JX448370, JX448371, JX448372, JX448373, KF791028, NC001785, X97251) were aligned using Vector NTI Advance 11.0 software. Then, the conserved region (4337-4472 bp) within the CI domain was chosen to design primers, which were predicted to be able to detect all known PRSV isolates. Likewise, based on the alignment result of the $C P$ gene sequences of the PLDMV and PapMV isolates available in GenBank (PLDMV isolates Acc. Nos. AB088221, AB092814, AB092815, AB092816, XJ974555, D50082, JX416282, EU233272, EU240890, EF675245, EU240888, and EF240889; PapMV isolates Acc. Nos. AY017186, AY017187, AY017188, D00240, D13957, EF183500 and JX524226), conserved regions (9696-9823 bp and 6276-6460 bp) were chosen to design primers for detecting PLDMV and PapMV, respectively. The primers were designed using the Primer Premier 5 (version 5.00) software. The sequences of the various primers, primer locations, and product sizes are given in Table 1.

RNA extraction and cDNA synthesis. Total RNA was extracted from 50-100 mg of papaya leaves using TRIzol' (Invitrogen, USA) in accordance with the manufacturer's instructions. The concentration of RNA was determined by using the NanoVue ${ }^{\mathrm{TM}}$ Plus Spectrophotometer (GE Healthcare, USA). The first-strand cDNA was synthesized using TaKaRa PrimeScript ${ }^{\mathrm{TM}} \mathrm{RT}$ reagent kit with gDNA Eraser (Perfect Real Time, Takara, China) according to the manufacturer's instructions. For the genomic DNA elimination reaction, approximately $1 \mu \mathrm{g}$ of total RNA in $7 \mu \mathrm{l}$ of RNase free $\mathrm{dH}_{2} \mathrm{O}$ was combined with $1 \mu \mathrm{l}$ gDNA Eraser and $2 \mu \mathrm{l} 5 \times$ gDNA Eraser buffer, incubated at $42^{\circ} \mathrm{C}$ for $2 \mathrm{~min}$. The reverse-transcription reaction was performed in a final volume of $20 \mu \mathrm{l}$ containing $4.0 \mu \mathrm{l}$ $5 \times$ PrimeScript buffer 2 (for Real Time), $1.0 \mu$ PrimeScript RT enzyme mix I, $1.0 \mu \mathrm{l}$ RT Primer mix, $4.0 \mu \mathrm{l}$ RNase free $\mathrm{dH}_{2} \mathrm{O}$, and 10.0 $\mu \mathrm{l}$ reaction solution from the genomic DNA elimination reaction. Reverse transcription was carried out at $37^{\circ} \mathrm{C}$ for $15 \mathrm{~min}$, followed by $5 \mathrm{sec}$ at $85^{\circ} \mathrm{C}$, in a Thermocycler (Biometra, Germany).

Single real-time PCR with SYBR Green I. The single real-time PCR amplification was carried out using SYBR Premix Ex Taq ${ }^{\mathrm{TM}}$ II kit (Takara, China) under the following conditions: each $20 \mu \mathrm{l}$ reaction mixture consisted of $10 \mu$ of SYBR Premix Ex Taq ${ }^{\circ}$ II $(2 \times), 0.4 \mu \mathrm{l}$ ROX reference dye $(50 \times), 0.4 \mu \mathrm{mol} / \mathrm{l}$ of the forward and the reverse primer, and $2 \mu \mathrm{l}$ of template cDNA. All amplifications were performed on Stratagene MX3005P cycler (Stratagene, USA). After an initial heat denaturation step at $94^{\circ} \mathrm{C}$ for $5 \mathrm{~min}, 40$ cycles were programmed as follows: $95^{\circ} \mathrm{C}$ for $20 \mathrm{sec}, 55^{\circ} \mathrm{C}$ for $30 \mathrm{sec}$, and $72^{\circ} \mathrm{C}$ for $20 \mathrm{sec}$. To analyze the melting temperature (Tm), PCR products were heated to $95^{\circ} \mathrm{C}$ for $1 \mathrm{~min}$, cooled to $55^{\circ} \mathrm{C}$ for $30 \mathrm{sec}$, and slowly reheated to $95^{\circ} \mathrm{C}$ for $30 \mathrm{sec}$. Fluorescence was recorded at the end of each annealing step and during the warming phase of the melting segment from $55^{\circ} \mathrm{C}$ to $95^{\circ} \mathrm{C}$. The size of PCR products was verified by $2 \%$ gel electrophoresis and visualized with UV trans-illumination after ethidium bromide staining.

Optimization of multiplex real-time PCR for PRSV, PLDMV, and PapMV detection. For multiplex real-time PCR, artificial mixture of total plant RNA (100 ng) from the different papaya samples known to be infected with PRSV, PapMV, or PLDMV was reverse transcribed into cDNAs. The multiplex real-time PCR assays were performed the same as the single real-time PCR protocols. To 
Table 1 Oligonucleotide primers used in the multiplex real-time PCR

\begin{tabular}{|c|c|c|c|c|}
\hline Primer $^{\mathrm{a}}$ & Sequence $\left(5^{\prime}-3^{\prime}\right)$ & Size (bp) & Target & Position \\
\hline PRSV-F & CGACTTTGACATCACTGGTGAAA & 23 & \multirow{2}{*}{ PRSV-CI } & $4337-4359^{b}$ \\
\hline PRSV-R & GAACTCAACGAATGTTCCTCCAA & 23 & & $4450-4472^{\mathrm{b}}$ \\
\hline PLDMV-F & ATTCAACGGAACCTCACCGA & 20 & \multirow{2}{*}{ PLDMV-CP } & $9696-9715^{c}$ \\
\hline PLDMV-R & GCATCTCGTAATGCTGCTGCT & 21 & & $9808-9823^{c}$ \\
\hline PapMV-F & TCAGGATACAAGCCAAGCG & 19 & \multirow{2}{*}{ PapMV-CP } & $6276-6294^{\mathrm{d}}$ \\
\hline PapMV-R & CTGGCAAAGTTGTTGTCCTG & 20 & & $6441-6460^{d}$ \\
\hline
\end{tabular}

${ }^{\mathrm{a}} \mathrm{F}$ and $\mathrm{R}$ are for sense and antisense primer, respectively, used in real-time PCR. ${ }^{\mathrm{b}}$ Relative position on the complete genome sequence of papaya ringspot virus (GenBank Acc. No. KF791028). ' Relative position on the complete genome sequence of papaya leaf distortion mosaic virus (GenBank Acc. No. JX974555). ${ }^{\mathrm{d}}$ Relative position on the complete genome sequence of papaya mosaic virus (GenBank Acc. No. JX524226).

simultaneously amplify all three viral targets efficiently in one reaction, the denaturation temperature $\left(53,55,58\right.$, and $\left.60^{\circ} \mathrm{C}\right)$, extension time $(15,20,25$, and $30 \mathrm{sec})$ and three sets of virus-specific primers (PRSV-F/R + PLDMV-F/R+ PapMV-F/R) with twenty primer combinations for concentration $(0.02$ to $0.4 \mu \mathrm{mol} / \mathrm{l}$ of each primer pair) were optimized. Melting peaks were visualized by plotting the fluorescence $\left[-R^{\prime}(T)\right]$ against the melting temperature. The melting temperature $(\mathrm{Tm})$ was defined as the peak of the curve, and more than 100 tests were performed to achieve the range of specific $\mathrm{Tm}$ for each virus. For electrophoretic analysis, PCR products (10 $\mu \mathrm{l})$ were separated on a $2 \%$ agarose gel in TAE buffer at $130 \mathrm{~mA}$ for 20 min and visualized with trans-illumination of ethidium bromide staining.
Specificity and sensitivity of the multiplex real-time PCR. The specificity of the multiplex real-time PCR assay was evaluated using papaya leaves known to be infected with PLDMV, PRSV, or PapMV based on the above-mentioned protocols. To determine the sensitivity of the single and multiplex real-time PCR assays, the $136 \mathrm{bp}$ amplicon of the CI segment of PRSV, $128 \mathrm{bp}$ amplicon of the CP segment of PLDMV, and the $185 \mathrm{bp}$ amplicon of CP segment of PapMV (all the primers were described in Table 1) were cloned individually in the pMD18-T vector (Takara, China). The resulting plasmid constructs, named pPRSV-CI136, pPLDMVCP128, and pPapMV-CP185, were confirmed by sequencing (Life Technologies, China) and were used as the standard templates for real-time PCR. The concentrations of the plasmids were

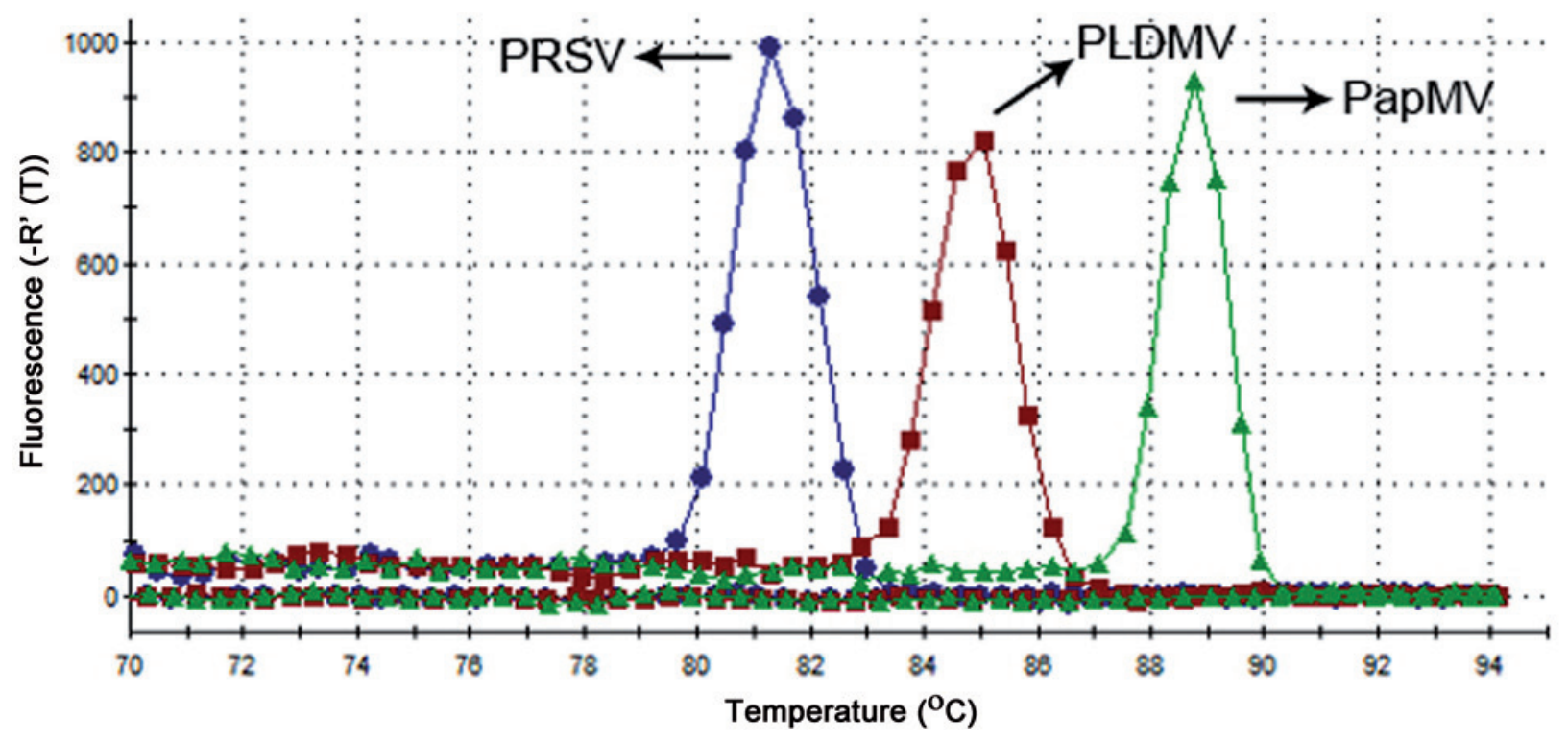

Fig. 1

Single real-time PCR dissociation curves of PRSV, PLDMV, and PapMV indicating the melting temperatures of $81.30^{\circ} \mathrm{C}, 8^{85.05}{ }^{\circ} \mathrm{C}$, and $88.78^{\circ} \mathrm{C}$, respectively 
determined by the NanoVue ${ }^{\mathrm{TM}}$ ultraviolet spectrophotometer (GE Healthcare, USA). The number of gene copies in each dilution was calculated according to the following formula: copies/ $\mu \mathrm{l}=\left(6.02 \times 10^{23}\right) \times\left(\right.$ plasmid concentration $\left.(\mathrm{ng} / \mu \mathrm{l}) \times 10^{-9}\right) /(\mathrm{DNA}$ length $(\mathrm{bp}) \times 660)($ Yue et al., 2009). The sensitivities of the single and multiplex real-time PCRs were analyzed based on the Tm, slope, and $\mathrm{R}^{2}$ values. To determine the sensitivity of the single and multiplex real-time PCR assays, the 10-fold serial dilutions ranging from $1 \times 10^{1}$ to $1 \times 10^{9}$ gene copies per $2 \mu \mathrm{l}$ of the standard plasmids, were diluted with nuclease-free water. The sensitivity of the assays was determined from three independent replicates and in each reaction we used $2 \mu$ of the DNA sample. Standard curves were constructed using mean threshold cycle (Ct) and log inputs of various DNA copies. The analytical sensitivities of the single and multiplex real-time PCR were compared to evaluate the effect of the multiple real-time PCR system on the analytical sensitivity of the test.

Detection of field samples by multiplex real-time RT-PCR and multiplex RT-PCR. A total of 180 papaya leaf samples were collected from Haikou, Sanya and Ledong of Hainan Island between March and May 2014. Among these 180 samples, 100 samples displayed some disease symptoms such as mosaic, distortion, and ring spots on leaves; the rest of the samples showed no symptoms. The multiplex real-time PCR assay was performed as described above and its detection rate was compared to that of multiplex RT-PCR (Tuo et al., 2014).

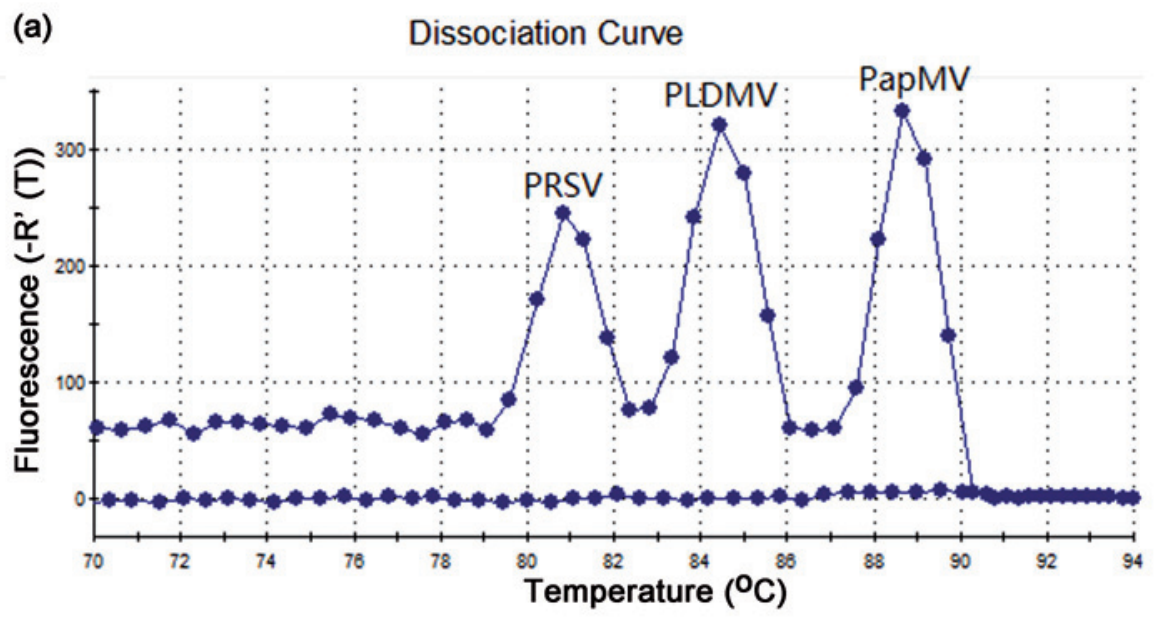

(b)

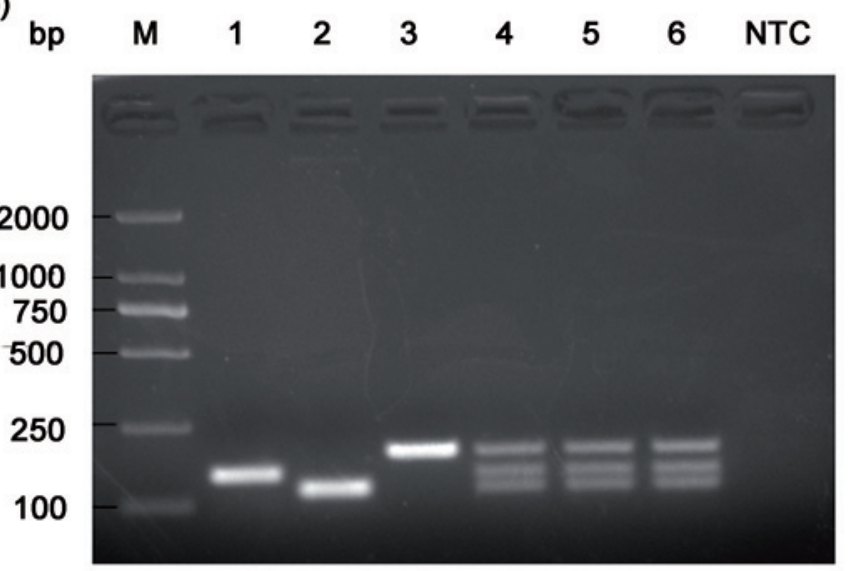

Fig. 2

The dissociation curve and agarose gel electrophoresis for multiplex real-time RT-PCR

The dissociation curve of SYBR Green I-based multiplex real-time RT-PCR (a) showed three distinct peaks representing the Tm of PRSV-, PLDMV-, and PapMV-specific products. The peak for the $136 \mathrm{bp}$ PRSV amplicon, $128 \mathrm{bp}$ PLDMV amplicon, and $185 \mathrm{bp}$ PapMV amplicon were found at $80.83^{\circ} \mathrm{C}$, $84.45^{\circ} \mathrm{C}$, and $88.65^{\circ} \mathrm{C}$, respectively. Agarose gel electrophoresis of multiplex real-time RT-PCR products (b) 2000 bp DNA ladder (M); PRSV positive template control 136 bp (lane 1); PLDMV positive template control, 128 bp (lane 2); PapMV positive template control, 185 bp (lane 3); agarose gel electrophoresis of multiplex real-time PCR products in triplicate (lanes 4-6); negative template control (lane NTC). 


\section{Results}

\section{Single real-time PCR with SYBR Green I}

The single real-time PCR with triplicate samples was utilized to measure individually the average Tm of amplicons from the PRSV, PLDMV, or PapMV cDNA. Each distinct melting peak generated at a specific temperature represents an amplicon in the melting curve. The melting curve analysis showed that a single specific melt peak occurred at $\mathrm{Tm}=81.2 \pm 0.3^{\circ} \mathrm{C}$ for PRSV, Tm $=84.9 \pm 0.3^{\circ} \mathrm{C}$ for PLDMV, or $\mathrm{Tm}=88.8 \pm 0.2^{\circ} \mathrm{C}$ for PapMV (Fig. 1). These amplification products were also confirmed by electrophoresis with a $2 \%$ agarose gel (data not shown). Therefore, it is possible to use these primers to distinguish the three viruses using multiplex real-time PCR since the Tm of the three viruses were significantly different from each other in the single real-time PCR.

\section{Establishment of multiplex real-time PCR for PRSV,} $P L D M V$, and PapMV detection

The real-time PCR protocol was optimized according to the denaturation temperature, extension time, and concentrations of primers. When the multiplex real-time PCR was carried out at the following conditions, $95^{\circ} \mathrm{C}$ for $20 \mathrm{sec}, 55^{\circ} \mathrm{C}$ for $30 \mathrm{sec}$, and $72^{\circ} \mathrm{C}$ for $20 \mathrm{sec}$, all three viral targets could be simultaneously amplified with high specificity in a single reaction. To obtain balanced amplification of the three viral target genes, twenty
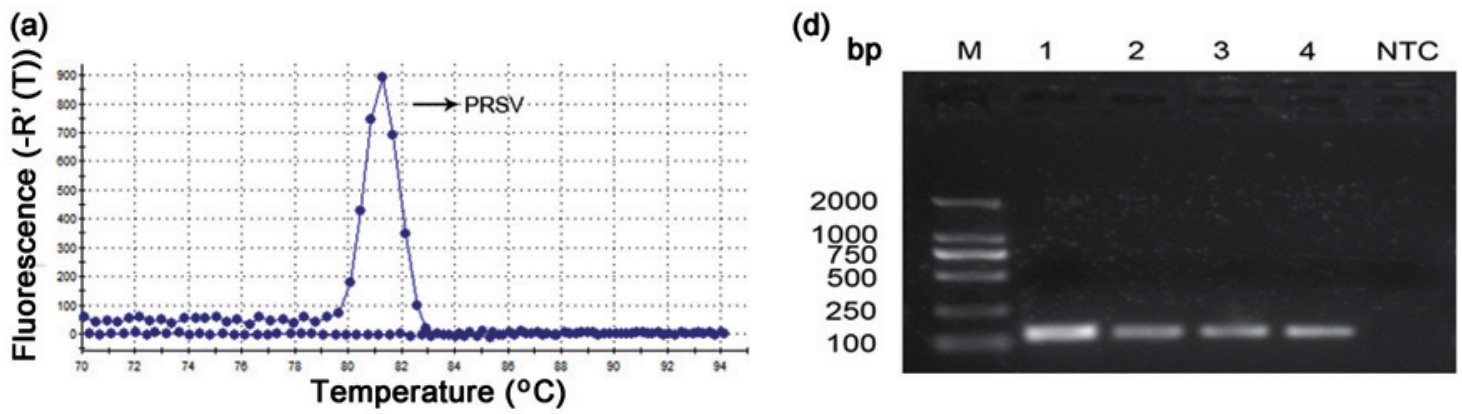

(b)

(e)
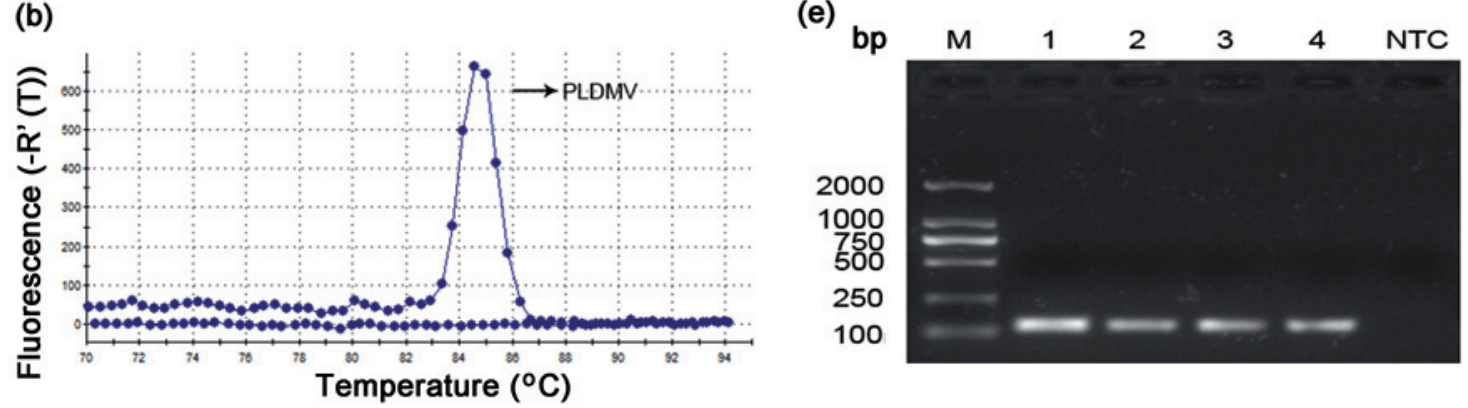

(c)

(f)
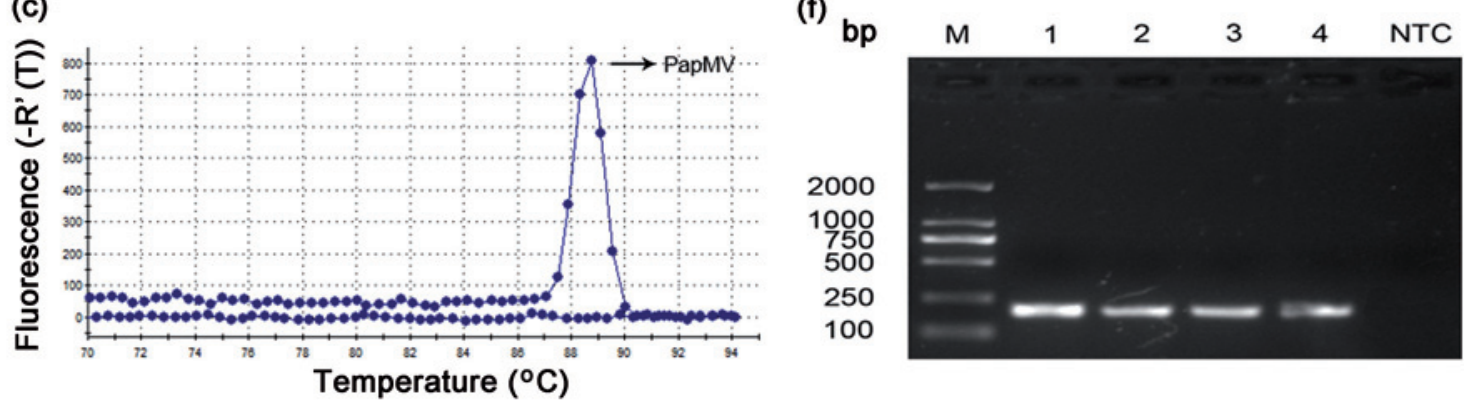

Fig. 3

Specificity analysis of multiplex real-time PCR and gel analysis for PRSV, PLDMV, and PapMV

The melting curves $(a, b, c)$ and agarose gel electrophoresis $(d, e, f)$ of multiplex real-time PCR products showed the specificity of multiplex real-time PCR for PRSV (a, d), PLDMV (b, e) and PapMV (c, f). The peaks of the melting curves for $136 \mathrm{bp} \mathrm{PRSV} \mathrm{amplicon,} 128$ bp PLDMV amplicon, and $185 \mathrm{bp}$ PapMV amplicon were found at $81.28^{\circ} \mathrm{C}, 84.58^{\circ} \mathrm{C}$, and $88.78^{\circ} \mathrm{C}$, respectively. 2000 bp DNA ladder (M); positive control (PRSV-136bp, PLDMV-128bp, PapMV-185bp) (lane 1); multiplex real-time PCR products in triplicate (lanes 2-4); negative template control (lane NTC). 
combinations of primer concentration $(0.02$ to $0.4 \mu \mathrm{mol} / \mathrm{l}$ of each primer pair) were performed. The melting curves showed three specific peaks corresponding to the $\mathrm{Tm}=81.0 \pm 0.8^{\circ} \mathrm{C}$ for PRSV, $\mathrm{Tm}=84.7 \pm 0.6^{\circ} \mathrm{C}$ for PLDMV, or Tm $=88.7 \pm 0.4^{\circ} \mathrm{C}$ for PapMV when the primer concentrations were at $0.4 \mu \mathrm{mol} / 1$ PRSV-F/R for PRSV, $0.1 \mu \mathrm{mol} / 1$ PLDMV-F/R for PLDMV, and $0.05 \mu \mathrm{mol} / \mathrm{l}$ PapMV-F/R for PapMV (Fig. 2a). Agarose gel analysis of multiplex real-time PCR proved presence of PCR products of expected size (Fig. 2b).

\section{Specificity of the multiplex real-time PCR}

Total RNA from papaya leaves known to be singly infected with PRSV, PLDMV, or PapMV was reverse-transcribed into
cDNA, then used to determine the specificity of the primers used in the multiplex real-time PCR assay. The melting curve analysis showed only a single peak with the Tm closely matching those of the single reactions in samples infected with PRSV, PLDMV or PapMV (Fig. 3).

\section{Sensitivity of the multiplex real-time PCR}

The standard curve analysis revealed a strong linear relationship between the $\mathrm{Ct}(\mathrm{dRn})$ values and the $\log _{10}$ value of the initial plasmid copy number for the positive control plasmid samples $\left(\mathrm{R}_{\text {PRSV }}^{2}, \mathrm{R}_{\text {PLDMV }}^{2}\right.$, and $\mathrm{R}_{\text {PapMV }}^{2}=0.985$ or better) in the single (Fig. $4 \mathrm{a}-\mathrm{c}$ ) and multiplex real-time RT-PCR (Fig. 4d-f). The single real-time RT-PCR had (a)

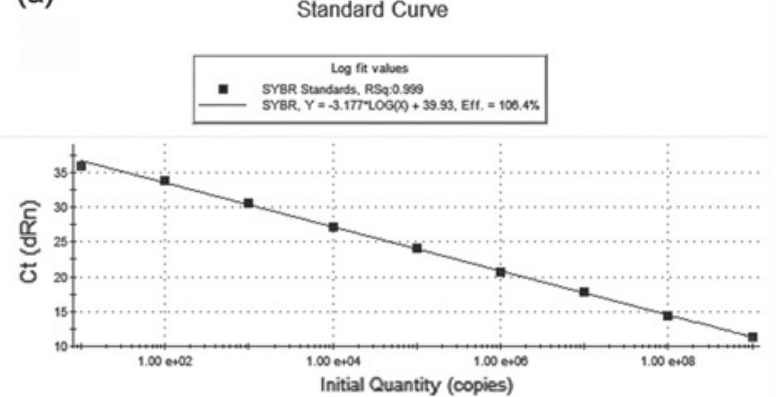

(b)

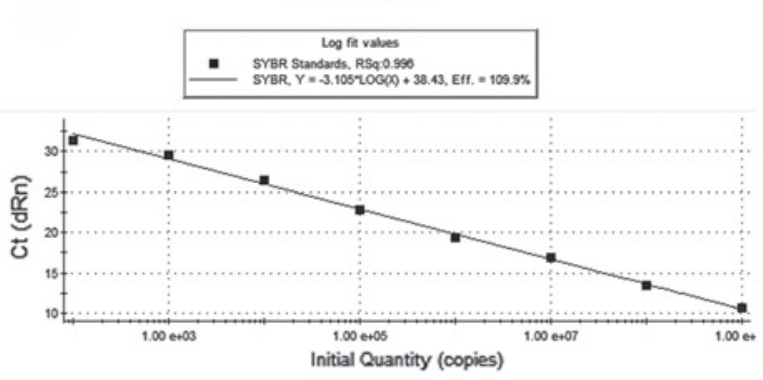

(c)

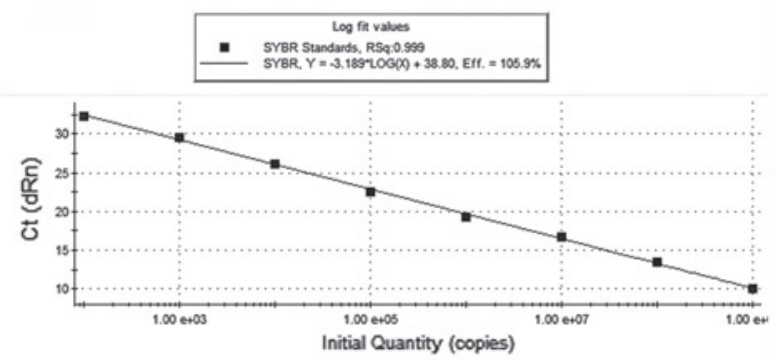

(d)

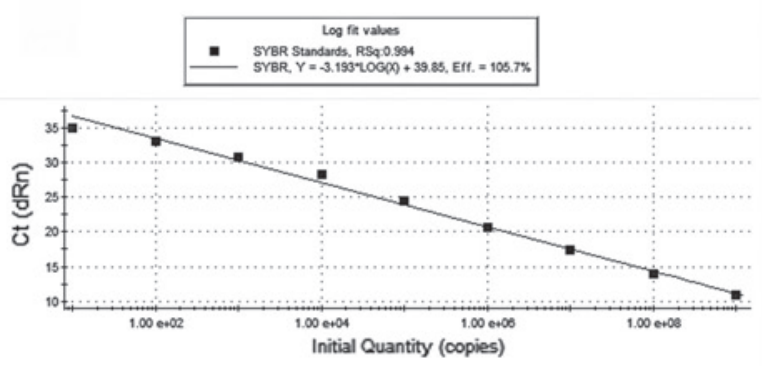

(e)

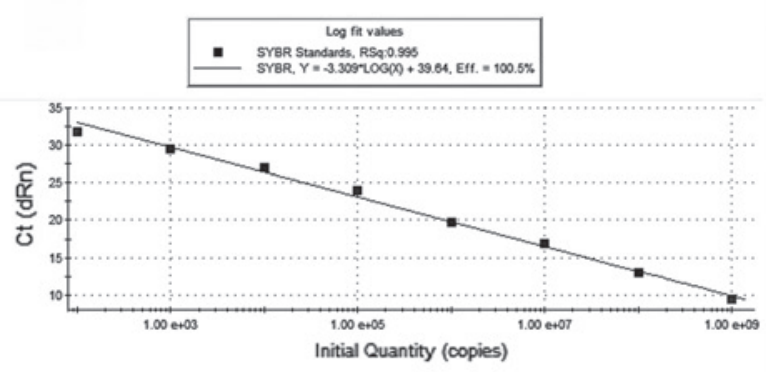

(f)

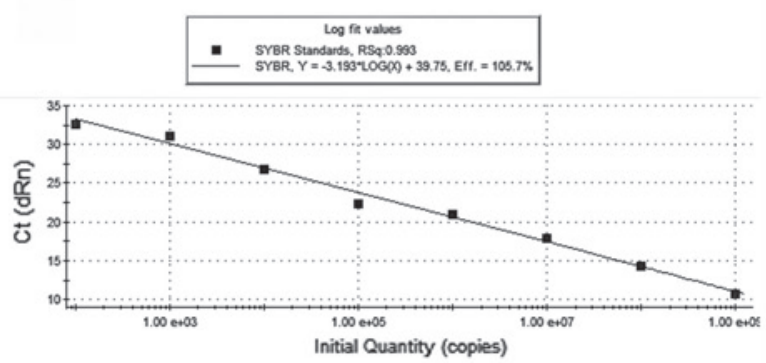

Fig. 4

Sensitivity analysis of single and the multiplex real-time PCR by the standard curves

The standard curves analysis showed a linear relationship between the $\mathrm{Ct}(\mathrm{dRn})$ values on the $\mathrm{x}$-axis and the $\log _{10}$ value of the plasmid copy number on Y-axis in the single (a-c) and multiplex real-time PCR (d-f) for PRSV (a, d), PLDMV (b,e) and PapMV(c, f).The experiment was performed in triplicate. The equation of the line of best fit and the coefficient of correlation $\left(\mathrm{R}^{2}\right)$ are represented on the graph. 
Table 2. Detection results of field samples obtained by multiplex SYBR Green I real-time PCR and multiplex RT-PCR on Hainan Island

\begin{tabular}{|c|c|c|c|c|c|c|c|c|c|c|c|}
\hline \multirow{2}{*}{$\begin{array}{l}\text { Type of } \\
\text { samples }\end{array}$} & \multirow{2}{*}{$\begin{array}{l}\text { No. of } \\
\text { samples }\end{array}$} & \multicolumn{5}{|c|}{ Detection result by multiplex RT-PCR ${ }^{*}$} & \multicolumn{5}{|c|}{$\begin{array}{c}\text { Detection result by multiplex real-time RT-PCR } \\
\text { (the ranges of Ct-values) }\end{array}$} \\
\hline & & $\begin{array}{l}\text { PRSV } \\
\text { only }\end{array}$ & $\begin{array}{l}\text { PLDMV } \\
\text { only }\end{array}$ & $\begin{array}{l}\text { PapMV } \\
\text { only }\end{array}$ & $\begin{array}{l}\text { PRSV + } \\
\text { PLDMV }\end{array}$ & Healthy & $\begin{array}{l}\text { PRSV } \\
\text { only }\end{array}$ & $\begin{array}{l}\text { PLDMV } \\
\text { only }\end{array}$ & $\begin{array}{l}\text { PapMV } \\
\text { only }\end{array}$ & $\begin{array}{l}\text { PRSV + } \\
\text { PLDMV }\end{array}$ & Healthy \\
\hline $\begin{array}{l}\text { Symptomatic } \\
\text { plants }\end{array}$ & 100 & 57 & 32 & 5 & 6 & 0 & $\begin{array}{c}57 \\
(8.34-26.34)\end{array}$ & $\begin{array}{c}32 \\
(11.14-27.58)\end{array}$ & $\begin{array}{c}5 \\
(13.35-20.76)\end{array}$ & $\begin{array}{c}6 \\
(11.14-28.86)\end{array}$ & 0 \\
\hline $\begin{array}{l}\text { Non-sympto- } \\
\text { matic plants }\end{array}$ & 80 & 0 & 3 & 0 & 0 & 77 & 0 & $\begin{array}{c}9 \\
(24.42-36.28)\end{array}$ & 0 & $\begin{array}{c}3 \\
(21.33-35.95)\end{array}$ & $\begin{array}{c}68 \\
\text { (No Ct) }\end{array}$ \\
\hline Total & 180 & 57 & 35 & 5 & 6 & 77 & 57 & 41 & 5 & 9 & 68 \\
\hline
\end{tabular}

*The multiplex RT-PCR was carried out in our previous study (Tuo et al., 2014).

the same detection limits as multiplex real-time RT-PCR, which was able to detect template up to $1.0 \times 10^{1}$ copies, 1.0 $\times 10^{2}$ copies, and $1.0 \times 10^{2}$ copies for PRSV, PLDMV, and PapMV, respectively.

\section{Diagnostics of PRSV, PLDMV, and PapMV in field} samples

In 100 symptomatic samples, both the multiplex real-time RT-PCR and multiplex RT-PCR showed 57/100 (57\%), 32/100 (32\%), or 5/100 (5\%) positive samples for PRSV, PLDMV and PapMV respectively, while doubleinfection for PRSV and PLDMV showed 6/100 (6\%) of positive samples. In the 80 non-symptomatic samples, 9 non-symptomatic were positive for PLDMV by multiplex real-time RT-PCR assay but only 3 samples were positive by multiplex RT-PCR. In addition, 3 non-symptomatic samples were positive for both PRSV and PLDMV by multiplex real-time RT-PCR assay but positive for PLDMV only by multiplex RT-PCR (Table 2). In contrast, the remaining 68 non-symptomatic samples were negative for PRSV, PLDMV, and PapMV by both the multiplex real-time RT-PCR and multiplex RT-PCR.

\section{Discussion}

PRSV infections have caused great economic losses in papaya farming on Hainan Island (Lu et al., 2008; Tuo et al., 2014). Moreover, PLDMV and PapMV have been found on Hainan Island, indicating two potential new threats for papaya production (Tuo et al., 2013; Shen et al., 2014a). Both the single infection of PRSV, PLDMV or PapMV and double infections of PRSV and PLDMV or PapMV caused indistinguishable symptoms in papaya plants (Cruz et al., 2009; Shen et al., 2014b; Tuo et al., 2014). Consequently, there is a need for rapid and accurate detection methods for the three viruses to enable better efforts to control and manage these viruses.

There are two main methods used to perform real-time PCR: dye-based and probe-based detection. The probebased systems such as TaqMan real time PCR can reduce background and false positives because probes are specific for their targets (Papin et al., 2004; Richards et al., 2004). However, viruses including PRSV and PLDMV have generally the high level of genetic diversity in sequences among the different strains (Akhter et al., 2013; Lu et al., 2008; Olarte Castillo et al., 2011; Tuo et al., 2013), the probe-based real time RT-PCR assays require high sequence identity for successful probe binding that frequently leads to false negative results and loss of sensitivity (Papin et al., 2004; Richards et al., 2004). Therefore, dyes as detection tools can be more suitable to detect the virus infection because they are potentially less influenced by mismatches for sequence variation in the probe target region. In addition, dyes such as SYBR Green I that intercalate into double-stranded DNA are less expensive than probes (Alvarez and Doné, 2014). In the current study, a low cost, rapid and reliable multiplex real-time PCR system based on SYBR Green I was developed for the simultaneous detection of PRSV, PLDMV, and PapMV in papaya.

As reaction complexity increases in the multiplex realtime PCR system compared to single real-time PCR, so does the probability that primers will dimerize or that competition for reaction components will limit the amplification of one or more targets (Doellinger et al., 2012). To counteract this trend, primer sets were designed based the best output-scores graded by Primer Premier 5 software for each primer pair and specificity for the targets of interest by BLAST searches. In this study, to detect virus isolates of different geographic origins, the primers were selected from the conserved region of $C P$ gene, except for PRSV from the conserved region of $C I$ 
gene because of the commercialization of transgenic papaya lines carrying the $C P$ gene of PRSV. The results of the multiplex real-time reverse transcription PCR confirmed that primers designed in this study can be used to simultaneously detect PRSV, PLDMV, and PapMV based on their distinctive Tms: $81.0 \pm 0.8^{\circ} \mathrm{C}$ for PRSV, $84.7 \pm 0.6^{\circ} \mathrm{C}$ for PLDMV, and $88.7 \pm 0.4^{\circ} \mathrm{C}$ for PapMV. Furthermore, to avoid biased detection rates, it is very important to obtain an even amplification of all target fragments in the multiplex real-time RT-PCR reaction (Czerny, 1996). However, a first provisional multiplex system test showed the PapMV amplicon was produced at a higher efficiency as the other two virus amplicons. After decreasing the PapMV primer concentrations resulted in balanced amplification efficiency for all three viral targets when a mix of template was used.

Many studies revealed that the sensitivity of multiplex real-time PCR based on SYBR Green I is much higher than that of the other diagnostic methods for viruses (Ong et al., 2007; Sharma and Dasgupta, 2012; Zheng et al., 2013). In this work, high sensitivity levels were obtained, with limits of detection of $10^{1}$ copies/reaction for PRSV, $10^{2}$ copies/reaction for PLDMV, and $10^{2}$ copies/reaction for PapMV from papaya leaves, which is an approximately 100-fold (for PRSV) and 10-fold (for PLDMV) higher sensitivity than the multiplex RT-PCR assay (Tuo et al., 2014). Moreover, the multiplex real-time PCR had a similar sensitivity to single real-time PCR for detection of PRSV, PLDMV, and PapMV although more than one primer pair may easily result in partial loss of the sensitivity in a single reaction of multiplex real-time PCR system (Doellinger et al., 2012), which owed to the selection of primer pairs and the optimization of some parameters such as concentrations of primers, denaturation temperature, and extension time. The field application of the multiplex real-time PCR assay demonstrated that six of the leaf samples with no symptoms that were positive for PLDMV by multiplex real-time RT-PCR assay but negative by multiplex RT-PCR, and three samples were positive for both PRSV and PLDMV by multiplex realtime RT-PCR assay but negative for PRSV by multiplex RT-PCR. This suggests that multiplex real-time RT-PCR is a better method for the detection of lower titers of PRSV and PLDMV, especially when used to monitor the early stages of virus infection in the field. In addition, 9 field samples were positive for co-infection of PRSV and PLDMV. Therefore, this approach is useful for rapid identification of mixed infections.

In conclusion, this is the first report of multiplex real-time RT-PCR for the diagnosis of PRSV, PLDMV and PapMV. This method will provide an alternative rapid, highly sensitive, reliable and cost-effective diagnostic tool to identify these three papaya viruses and detect the mixed infections in papaya.
Acknowledgements. This work was supported by the National Natural Science Foundation of China (grant Nos. 31371918 and 31171822).

\section{References}

Akhter MS, Basavaraj YB, Akanda AM, Mandal B, Jain RK (2013): Genetic diversity based on coat protein of Papaya ringspot virus (Pathotype P) isolates from Bangladesh. Indian J. Virol. 24, 70-73.

Alvarez ML, Doné SC (2014): SYBR ${ }^{\oplus}$ Green and TaqMan ${ }^{\bullet}$ quantitative PCR arrays: expression profile of genes relevant to a pathway or a disease state. Methods Mol. Biol. 1182, 321-359. http://dx.doi.org/10.1007/978-1-4939-1062$\underline{5 \quad 27}$

Bau HJ, Kung YJ, Raja JA, Chan SJ, Chen KC, Chen YK, Wu HW, Yeh SD (2008): Potential threat of a new pathotype of Papaya leaf distortion mosaic virus infecting transgenic papaya resistant to Papaya ringspot virus. Phytopathology 98, 848-856. http://dx.doi.org/10.1094/ PHYTO-98-7-0848

Chiang CH, Wang JJ, Jan FJ, Yeh SD, Gonsalves D (2001): Comparative reactions of recombinant papaya ringspot viruses with chimeric coat protein (CP) genes and wild-type viruses on CP-transgenic papaya. J. Gen. Virol. 82, 2827-2836. http://dx.doi.org/10.1099/0022-1317-82-11-2827

Cruz FC, Tanada JM, Elvira PR, Dolores LM, Magdalita PM, Hautea DM, Hautea RA (2009): Detection of mixed virus infection with Papaya ringspot virus (PRSV) in Papaya (Carica papaya L.) grown in Luzon, Philippines. Philipp. J. Crop Sci. 34, 62-74.

Czerny T (1996): High primer concentration improves PCR amplification from random pools. Nucleic Acids Res. 24, 985-986. http://dx.doi.org/10.1093/nar/24.5.985

Doellinger J, Schroeder K, Witt N, Heunemann C, Nitsche A (2012): Comparison of real-time PCR and MassTag PCR for the multiplex detection of highly pathogenic agents. Mol. Cell Probes 26, 177-181. http://dx.doi.org/10.1016/j. mcp.2012.07.002

Gonsalves D (1998): Control of papaya ringspot virus in papaya: a case study. Annu. Rev. Phytopathol. 36, 415-437. http:// dx.doi.org/10.1146/annurev.phyto.36.1.415

Ling K, Namba S, Gonsalves C, Slightom JL, Gonsalves D (1991): Protection against detrimental effects of potyvirus infection in transgenic tobacco plants expressing the Papaya ringspot virus coat protein gene. Biotechnology (NY) 9, 752-758. http://dx.doi.org/10.1038/nbt0891-752

Lu YW, Shen WT, Zhou P, Tang QJ, Niu YM, Peng M, Xiong $Z$ (2008): Complete genomic sequence of a Papaya ringspot virus isolate from Hainan Island, China. Arch. Virol. 153, 991-993. http://dx.doi.org/10.1007/s00705008-0056-3

Maoka T, Kashiwazaki S, Tsuda S, Usugi T, Hibino H (1996): Nucleotide sequence of the capsid protein gene of papaya leafdistortion mosaic potyvirus. Arch. Virol. 141, 197-204. http://dx.doi.org/10.1007/BF01718601 
Nicolas L, Milon G, Prina E (2002): Rapid differentiation of old world Leishmania species by light cycler polymerase chain reaction and melting curve analysis. J. Microbiol. Methods 51, 295-299. http://dx.doi.org/10.1016/S01677012(02)00099-4

Noa-Carrazana JC, González-de-León D, Ruiz-Castro BS, Pi-ero D, Silva-Rosales L (2006): Distribution of Papaya ringspot virus and Papaya mosaic virus in papaya plants (Carica papaya) in Mexico. Plant Dis. 90, 1004-1011. http:// dx.doi.org/10.1094/PD-90-1004

Olarte Castillo XA, Fermin G, Tabima J, Rojas Y, Tennant PF, Fuchs M, Sierra R, Bernal AJ, Restrepo S (2011): Phylogeography and molecular epidemiology of Papaya ringspot virus. Virus Res. 159, 132-140. http://dx.doi.org/10.1016/j. virusres.2011.04.011

Ong WT, Omar AR, Ideris A, Hassan SS (2007): Development of a multiplex real-time PCR assay using SYBR Green 1 chemistry for simultaneous detection and subtyping of H9N2 influenza virus type A. J Virol Methods 144, 57-64. http://dx.doi.org/10.1016/j.jviromet.2007.03.019

Papin JF, Vahrson W, Dittmer DP (2004): SYBR green-based realtime quantitative PCR assay for detection of West Nile virus circumvents false-negative results due to strain variability. J. Clin. Microbiol. 42, 1511-1518. http://dx.doi. org/10.1128/JCM.42.4.1511-1518.2004

Pérez LJ, Perera CL, Frías MT, Nú-ez JI, Ganges L, Arce HD (2012): A multiple SYBR Green I-based real-time PCR system for the simultaneous detection of porcine circovirus type 2 , porcine parvovirus, pseudorabies virus and Torque teno sus virus 1 and 2 in pigs. J. Virol. Methods 179, 233-241. http://dx.doi.org/10.1016/j.jviromet.2011.11.009

Richards GP, Watson MA, Kingsley DH (2004): A SYBR green real time RT-PCR method to detect and quantitate Norwalk virus in stools. J. Virol. Methods 116, 63-70. http://dx.doi. org/10.1016/j.jviromet.2003.10.011

Ririe KM, Rasmussen RP, Wittwer CT (1997): Product differentiation by analysis of DNA melting curves during the polymerase chain reaction. Anal. Biochem. 245, 154-160. http://dx.doi.org/10.1006/abio.1996.9916

Schweiggert RM, Kopec RE, Villalobos-Gutierrez MG, Högel J, Quesada S, Esquivel P, Schwartz SJ, Carle R (2014): Carotenoids are more bioavailable from papaya than from tomato and carrot in humans: a randomised cross-over study. Br. J. Nutr. 111, 490-498. http://dx.doi.org/10.1017/ $\underline{\text { S0007114513002596 }}$

Sharma S, Dasgupta I (2012): Development of SYBR Green I based real-time PCR assays for quantitative detection of Rice tungro bacilliform virus and Rice tungro spherical virus. J. Virol. Methods 181, 86-92. http://dx.doi.org/10.1016/j. jviromet.2012.01.018

Shen W, Yan P, Gao L, Pan X, Wu J, Zhou P (2010): Helper component-proteinase (HC-Pro) protein of Papaya ringspot virus interacts with papaya calreticulin. Mol. Plant Pathol. 11, 335-346. http://dx.doi.org/10.1111/j.1364-3703 2009.00606.X

Shen W, Wang Y, Tuo D, Yan P, Yang Y, Li X, Zhou P (2014a): Agroinoculation of Carica papaya with infectious clones of Papaya mosaic virus. Acta Virol. 58, 380-382. http:// dx.doi.org/10.4149/av $2014 \quad 04 \quad 380$

Shen W, Tuo D, Yang Y, Yan P, Li X, Zhou P (2014b): First report of mixed infection of Papaya ringspot virus and Papaya leaf distortion mosaic virus on Carica papaya L. J. Plant Pathol. S4, 121.

Shen W, Tuo D, Yan P, Li X, Zhou P (2014c): Detection of Papaya leaf distortion mosaic virus by reverse-transcription loop-mediated isothermal amplification. J. Virol. Methods 195, 174-179. http://dx.doi.org/10.1016/j. jviromet.2013.09.011

Sit TL, AbouHaidar MG (1993): Infectious RNA transcripts derived from cloned cDNA of papaya mosaic virus: effect of mutations to the capsid and polymerase proteins. J. Gen. Virol. 74, 1133-1140. http://dx.doi.org/10.1099/0022$\underline{1317-74-6-1133}$

Tuo D, Shen W, Yan P, Li C, Gao L, Li X, Li H, Zhou P (2013): Complete genome sequence of an isolate of papaya leaf distortion mosaic virus from commercialized PRSV-resistant transgenic papaya in China. J. Acta Virol. 57, 452-455. http://dx.doi.org/10.4149/av $2013 \quad 04 \quad 452$

Tuo D, Shen W, Yang Y, Yan P, Li X, Zhou P (2014): Development and validation of a multiplex reverse transcription PCR assay for simultaneous detection of three papaya viruses. Viruses 6, 3893-3906. http://dx.doi.org/10.3390/ $\underline{\mathrm{v} 6103893}$

Varga A, James D (2006): Real-time RT-PCR and SYBR Green I melting curve analysis for the identification of Plum pox virus strains C, EA, and W: Effect of amplicon size, melt rate, and dye translocation. J. Virol. Methods 132, 146-153. http://dx.doi.org/10.1016/j. jviromet.2005.10.004

Ye Ch, Li H (2010): 20 years of transgenic research in China for resistance to Papaya ringspot virus. Transgenic Plant J. $4,58-63$.

Yue F, Cui S, Zhang C, Yoon KJ (2009): A multiplex PCR for rapid and simultaneous detection of porcine circovirus type 2 , porcine parvovirus, porcine pseudorabies virus, and porcine reproductive and respiratory syndrome virus in clinical specimens. Virus Genes 38, 392-397. http:// dx.doi.org/10.1007/s11262-009-0333-6

Zheng LL, Wang YB, Li MF, Chen HY, Guo XP, Geng JW, Wang ZY, Wei ZY, Cui BA (2013): Simultaneous detection of porcine parvovirus and porcine circovirus type 2 by duplex real-time PCR and amplicon melting curve analysis using SYBR Green. J. Virol. Methods 187, 15-19. http:// dx.doi.org/10.1016/j.jviromet.2012.06.024 